\title{
Research on the Application of Cost Accounting in Higher Education Based on Activity-based Costing- - Take a Chinese Medicine University as an example
}

\author{
Bo $\mathrm{Su}^{1, *}$,Yu-qin $\mathrm{Chen}^{2}$, Xin-rui $\mathrm{Pi}^{3}$, and $\mathrm{Si}$-qi Feng ${ }^{4}$ \\ ${ }^{1,3,4}$ School of Management, Hubei University of Chinese Medicine, Wuhan 430065, China \\ ${ }^{2}$ College of Basic Medical Science, Hubei University of Chinese Medicine, Wuhan 430065, China
}

\begin{abstract}
Under the strategic layout of building world-class universities and first-class disciplines, the improvement of the quality requirements of graduates makes the input standard of higher education, namely the increase of education cost, attract wide attention. In this paper, taking the training cost of a Chinese medicine university as the implementation object, activity-based costing method is applied to the education cost accounting of the secondary college of this university, and the results are compared with the traditional cost accounting method, so as to analyze the adaptability and application value of activity-based costing method applied to the education cost of colleges and universities.
\end{abstract}

\section{The introduction}

As the "product" of higher education-students, namely the training object, all kinds of resource consumption in the process of training constitute the education cost. If we do not pay attention to the input and output of education, it will lead to the waste of financial expenditure and fail to benefit more young people with excellent higher education resources. Therefore, cost accounting and management of higher education are of vital importance to maximize the use of precious university resources.

\section{College education cost accounting}

\subsection{Concepts related to the cost of college education}

The concept of "education cost" was first put forward by the American educational economics theory, which came into being in the late 1950s and early 1960s. In 1986, Bruce Johnstone put forward the theory of "cost sharing in higher education", which caused extensive discussion and research on education cost in academic circles. At present, the cost of higher education is defined as the activity expenditures incurred by institutions of higher learning and other educational institutions on the recipients of education (students), including two parts: expense expenditure and capital expenditure ${ }^{[1]}$. Expenses refer to the consumption of human, financial, material and other resources in colleges and universities in teaching activities such as dissemination of knowledge, scientific research and creation activities, and other
activities.Capital expenditure refers to the capitalized expenditure in carrying out teaching activities, scientific research and other activities in universities.

The international definition of "education cost" has two dimensions: broad and narrow. Education cost in a broad sense starts from the perspective of education economics and is based on human capital theory and western economics. The narrow sense of education cost is based on the accounting perspective, which refers to the sum of the expenses paid by the school for cultivating students. Based on the current level and difficulty of university cost accounting, the cost accounting from the perspective of accounting has more practical significance. This paper also makes an empirical study on the cost accounting of university education from this perspective.

\subsection{College education cost accounting}

In the "Accounting System for Higher Education", direct education costs include education expenditures, scientific research expenditures, administrative expenditures and logistics support expenditures. Among them, some expenditures, such as administrative expenditures, logistics support expenditures, cannot be directly grouped into specific educational objects, and there are a large number of indirect costs that cannot be accurately calculated and allocated.

\subsection{The application of activity-based costing}

Activity Based Costing, also referred to as ABC Costing. In 1992, Robin Cooper, a young American scholar, and Robert Skaplan, a professor at Harvard University,

\footnotetext{
*Corresponding author: 150257076@qq.com
} 
developed and refined the previous theory. Activity-based costing began to be applied in the American industry. Whether direct costs are intuitive or indirect costs that cannot be defined directly, they are all included in the activity-based costing system of products or services consumed to facilitate accurate calculation of production costs. Its core idea is that "cost objects consume activities and activities consume resources".

The use of activity-based costing in education cost accounting in colleges and universities has changed the traditional cost accounting process, which is based on the single "output" cost allocation, and is a more reasonable cost collection process.In the traditional education cost accounting, there is no functional relationship between many indirect costs and the change of "output". If the cost accounting is simply based on the total amount of output, accurate cost information can not be obtained.From the perspective of activity-based costing, all the expenses that can be directly applied to educational objects can be directly attributed to "product" costs. If the cost cannot be allocated directly, it should be traced to the relevant operation steps, and then allocated to the final "product" cost after the cost of the operation steps is accurately calculated. Colleges and universities can obtain more accurate education costs by adopting activity-based costing, and clearly see the cost consumption and distribution path in the process of homework for different educational objects ${ }^{[2]}$.

As an advanced cost accounting method, whether activity-based costing method is suitable for cost accounting in colleges and universities and whether it has advantages compared with traditional cost accounting, this paper will calculate and analyze the education cost of a basic medical school of a university of Chinese medicine by two methods.

\section{Application of activity-based costing in college educational cost accounting}

The theoretical basis of activity-based costing is "products $\rightarrow$ activity,activity $\rightarrow$ resources". The different majors offered by various universities lead to inconsistent teaching costs and resource consumption. When calculating the cost of higher education, it can be constructed in steps and modules. The specific process is shown in Figure 1.

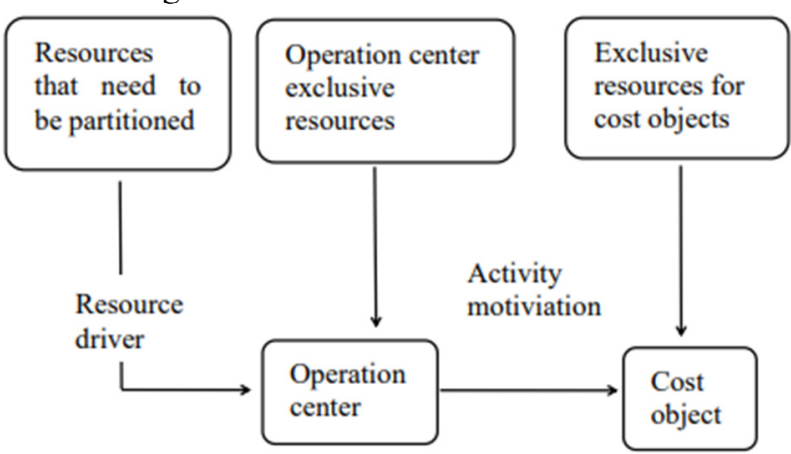

Fig 1. Education cost accounting process under activitybased costing

\subsection{Identification of activity}

Under $\mathrm{ABC}$ cost method, it is necessary to carry out resource analysis, activity differentiation, creation of activity center, definition of cost driver, return data to activity center, and then return data to the key steps of product production. From the actual situation, the department setup and management mode of most colleges and universities in China are quite similar. The tasks in colleges and universities usually include daily teaching, auxiliary teaching, scientific research, daily management of students, administrative management, asset management and so on. In the accounting of education cost, generally speaking, those directly related to the cultivation of students, such as teaching links, scientific research links and students' daily management,are the main tasks; Other administrative, teaching, assets, are indirect auxiliary work, as shown in Figure 2.

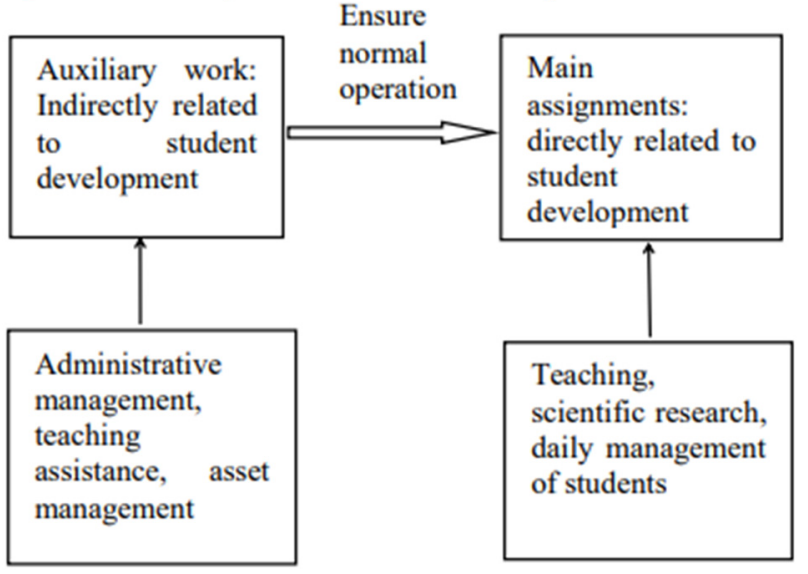

Fig 2. Colleges and universities education assignment recognition

\subsection{Analysis of the characteristics of college activity}

The daily education and teaching activities of colleges and universities can set up five operation centers.

\subsubsection{Teaching center, including core teaching work center and auxiliary teaching work center}

The core teaching operation center covers daily teaching activities of teachers, including daily classes, exam proposition, invigilation, marking, teaching skills improvement.

Assisting the teaching operation center, the work content includes the purchase and maintenance of library resources, the construction and maintenance of electronic reading room, science and technology experiment and practice training, the construction and maintenance of campus information network, the creation and repair of computer room.

\subsubsection{Scientific research operation center}

The work content includes the scientific research project funds supported by various levels from the national level 
to the university level and the supporting scientific research funds according to the requirements of public financial budget.

\subsubsection{Students activity management operation center}

Students daily management and comprehensive quality development and other activities, including scholarships, grants, enrollment publicity, ideological and political management, community activities, innovation and entrepreneurship support.

\subsubsection{Administrative management operation center}

Including the party and government, administrative personnel funds and public funds, organizational structure and personnel management, financial and internal audit risk control, discipline inspection.

\subsubsection{Asset service operation center}

The normal operation of the hardware facilities, including the purchase, maintenance and repair of teaching buildings, stadiums, scientific research instruments and equipment, and fixed assets.

\subsection{Resource driver analysis}

Resource driver is the key link of $\mathrm{ABC}$ costing method, and it is the standard to count resource consumption into activity center finally. The verification of resource driver directly affects the accuracy of ABC. The determination of resource motivation should follow the following principles: first, correlation, resource motivation is the real fact of resource consumption; The second is the convenience of access. Resource drivers are easy to obtain and measure in the accounting process. The third is the singleness. Each job only needs to be allocated according to one resource driver as the standard.In practice, if a resource is only used for a particular assignment, it can be directly credited to the assignment center, such as the award of individual student scholarships; However, some resources are not exclusive to a particular assignment, such as the allocation of water and electricity charges in classrooms, which should be reasonably allocated according to the actual situation, namely resources jointly used by multiple operation centers ${ }^{[4]}$. After the resource cost of each operation center is verified scientifically, the corresponding activity cost database will be established.

\subsection{Determine the motivation of the activity}

The assignment rate of activity drivers is calculated according to certain standards, and the cost consumption activities are collected into the object of cost accounting. Different universities should fully consider their own actual situation and actual needs to determine the motivation of activity ${ }^{[5]}$.

\section{An empirical study on education cost accounting by activity-based costing in a Chinese medicine university}

In order to verify the matching degree of the application of activity-based costing in the cost accounting of university education, and whether it is more advantageous to calculate the cost of university education through activity-based costing compared with traditional accounting methods, the author selected the relevant cost data of a university of traditional Chinese medicine in 2018 for calculation.

\subsection{Brief introduction of a university of Chinese medicine}

The University of Chinese Medicine covers all levels of education for undergraduates, masters, and doctoral students, and offers undergraduate majors in seven disciplines: medicine, science, engineering, management, literature, education, and economics. Set up 13 secondary schools and departments, including the School of Basic Medicine, the School of Traditional Chinese Medicine, the School of Management, and the School of Humanities. In 2018, the number of students in the school was 16,172 , 720 full-time teachers, 118 counselors, 160 teaching assistant experiment teachers, and 187 administrative positions.

The university's fixed assets mainly include buildings of 509,642.57 square meters, of which office buildings of 14,788.59 square meters; 35 cars; 39 sets of general equipment with a unit price of more than 500,000 yuan (including); 5 sets of special equipment whose unit price is more than 1 million yuan (including); The total value of teaching and research equipment is about 189 million yuan; There are about 1.53 million paper books and 4.15 million electronic books in the library.

Since 2014 , the university has started to calculate depreciation, and the assets have no residual value. The service life of fixed assets such as houses is 50 years, and the service life of general assets and scientific teaching and research instruments is 10 years. The depreciation of specific assets is shown in Table 1.

Table1. Depreciation calculation of fixed assets of a university of Chinese medicine in 2018

\begin{tabular}{|c|c|c|c|c|}
\hline Project & $\begin{array}{c}\text { Origin } \\
\text { al } \\
\text { value }\end{array}$ & $\begin{array}{c}\text { Tenure } \\
\text { of } \\
\text { use }\end{array}$ & $\begin{array}{c}\text { Yearly } \\
\text { depreciation }\end{array}$ & $\begin{array}{c}\text { Annual } \\
\text { depreciat } \\
\text { ion } \\
\mathbf{( 1 0 , 0 0 0} \\
\text { yuan) }\end{array}$ \\
\hline $\begin{array}{c}\text { Structu } \\
\text { re }\end{array}$ & 97912 & 50 & $2 \%$ & 1958 \\
\hline $\begin{array}{c}\text { Genera } \\
1 \text { assets }\end{array}$ & 19355 & 10 & $10 \%$ & 1936 \\
\hline
\end{tabular}




\begin{tabular}{|c|c|c|c|c|}
\hline $\begin{array}{c}\text { Scientif } \\
\text { ic } \\
\text { instrum } \\
\text { ents }\end{array}$ & 32000 & 10 & $10 \%$ & 3200 \\
\hline Total & & & 7094 \\
\hline
\end{tabular}

\subsection{Analysis on the related education cost of a Chinese medicine university in 2018}

According to the University of Traditional Chinese Medicine's 2018 financial statements and expenditure schedules, the expenditures that are not part of education costs are excluded, and various items related to education costs are accounted for. Wages and welfare expenditures and subsidies for individuals and families are all personnel expenditures to ensure the normal operation of operations, and they are combined into personnel expenditures and included in education costs. Among them, the leave allowance, retirement allowance, resignation allowance, pension, living allowance, external award and assistantship have nothing to do with the education, teaching and scientific research in the current school, so they shall be excluded. The following representative expenditure items are listed below, as shown in Table 2.

Table3. Resource motivation allocation table

\begin{tabular}{|c|c|c|c|c|c|c|c|c|}
\hline $\begin{array}{c}\text { Project } \\
\text { resources }\end{array}$ & $\begin{array}{c}\text { Amou } \\
n t\end{array}$ & $\begin{array}{l}\text { Resource } \\
\text { driver }\end{array}$ & $\begin{array}{c}\text { Teaching } \\
\text { managemen } \\
\mathrm{t}\end{array}$ & $\begin{array}{c}\text { Auxiliary } \\
\text { teaching }\end{array}$ & $\begin{array}{l}\text { Scientific research } \\
\text { management }\end{array}$ & $\begin{array}{c}\text { Student } \\
\text { management }\end{array}$ & $\begin{array}{c}\text { Administrative } \\
\text { management }\end{array}$ & $\begin{array}{c}\text { Asset } \\
\text { manageme } \\
\text { nt }\end{array}$ \\
\hline $\begin{array}{c}\text { Wage } \\
\text { expenditu } \\
\text { re }\end{array}$ & 19425 & $\begin{array}{l}\text { The actual } \\
\text { number }\end{array}$ & 11803 & 2623 & & 1934 & 3065 & \\
\hline $\begin{array}{c}\text { Scholarshi } \\
\text { ps }\end{array}$ & 2892 & Special way & & & & 2892 & & \\
\hline $\begin{array}{c}\text { Office } \\
\text { expenses }\end{array}$ & 1078 & $\begin{array}{l}\text { Office } \\
\text { number }\end{array}$ & 655 & 146 & & 107 & 170 & \\
\hline $\begin{array}{l}\text { scientific } \\
\text { research } \\
\text { funds }\end{array}$ & 14479 & Special way & & & 14479 & & & \\
\hline $\begin{array}{c}\text { Asset } \\
\text { maintenan } \\
\text { ce (repair) } \\
\text { fee }\end{array}$ & 67 & Special way & & & & & & 67 \\
\hline $\begin{array}{l}\text { Depreciati } \\
\text { on of } \\
\text { fixed } \\
\text { assets }\end{array}$ & 7094 & Special way & & & & & & 7094 \\
\hline Total & 45035 & - & 12458 & 2768 & 14479 & 4934 & 3235 & 7161 \\
\hline
\end{tabular}

By dividing the functional departments of the university, the following six activity-based cost databases
Table2. Details of 2018 education cost expenditure project of a university of Chinese medicine

\begin{tabular}{lc}
\hline \multicolumn{1}{c}{ Project } & $\begin{array}{c}\text { Amount } \\
(\mathbf{1 0}, \mathbf{0 0 0 y u a n})\end{array}$ \\
\hline Personnel expenditure & 22317.4 \\
Among them: & 19425 \\
wages and welfare expenditures & 2892.4 \\
Scholarships & 1145 \\
Public funds & 1078 \\
Among them: & 67 \\
Office expenses & 14478.55 \\
Asset maintenance (repair) fee & 37940.95 \\
\hline scientific research funds & \\
\hline Total &
\end{tabular}

The educational activities in colleges and universities are usually related to each other. According to the principle of resource motivation, the actual number of office workers and other factors such as the object of resource use and operation characteristics are taken as the resource motivation. First, the resources allocated by each operation center, such as wage expenditure and office expenses, can be directly taken as the resource driver according to the number of office workers. Second, the single used related resources, as the exclusive motivation of the operation, are directly included in the relevant operation center. Accordingly, the resource motivation allocation table of this school is defined as shown in Table 3 . are formed after resource allocation: teaching management, teaching assistance, scientific research 
management, student management, administrative management and asset management ${ }^{[3]}$, as shown in table 4.

Table4. Activity-based cost library

\begin{tabular}{|c|c|}
\hline Operation center & Cost amount \\
\hline Teaching management & 12458 \\
\hline Auxiliary teaching & 2768 \\
\hline Scientific research management & 14479 \\
\hline Student management & 4934 \\
\hline Administrative management & 3235 \\
\hline Asset management & 7161 \\
\hline Total & 45035 \\
\hline
\end{tabular}

\subsection{Analyze activity drivers, calculate activity drivers distribution rate and distribution cost}

Taking the School of Basic Medicine of the university as an example, and calculates the education cost of the school in 2018. The college has 816 students. According to the principle of the relevance of the operation center, in the operation process of the teaching management center and the teaching-auxiliary management center, the goal setting, process arrangement and result assessment are closely related to the actual class length of students, that is, the operation motivation is determined according to the number of class hours.Student management center, scientific research management center, administration management center,asset management center and other operation centers provide services for students. The operation motivation of these operation centers is determined by the number of students who actually receive operation services. The cost of basic medical school education is obtained by multiplying the actual consumption of basic medical school by matching the activity-based cost base and calculating the driver distribution rate. The calculation process is shown in Table 5.

Table5. Activity cost allocation of basic medical school

\begin{tabular}{|l|l|l|l|l|c|c|}
\hline \multicolumn{1}{|c|}{ Operation center } & Cost & \multicolumn{1}{|c|}{ Operation } \\
motivation & $\begin{array}{c}\text { Total } \\
\text { motivation }\end{array}$ & $\begin{array}{c}\text { Motivation } \\
\text { allocation } \\
\text { rate }\end{array}$ & $\begin{array}{c}\text { College } \\
\text { motivation }\end{array}$ & $\begin{array}{c}\text { Distribution } \\
\text { on costs }\end{array}$ \\
\hline Teaching management & 12458 & Actual class hours & 28478 & 0.4374 & 3492 & 1528 \\
\hline Auxiliary teaching & 2768 & Actual class hours & 28478 & 0.0972 & 3492 & 339 \\
\hline $\begin{array}{l}\text { Scientific researc } \\
\text { management }\end{array}$ & 14479 & $\begin{array}{c}\text { Actual number of } \\
\text { students }\end{array}$ & 16172 & 0.8953 & 816 & 731 \\
\hline Student management & 4934 & $\begin{array}{c}\text { Actual number of } \\
\text { students }\end{array}$ & 16172 & 0.3051 & 816 & 249 \\
\hline $\begin{array}{l}\text { Administrative } \\
\text { management }\end{array}$ & 3235 & $\begin{array}{c}\text { Actual number of } \\
\text { students }\end{array}$ & 16172 & 0.2001 & 816 & 163 \\
\hline Asset management & 7161 & $\begin{array}{c}\text { Actual number of } \\
\text { students }\end{array}$ & 16172 & 0.4428 & 816 & 361 \\
\hline Total & 45035 & & 121644 & & 10248 & 3371 \\
\hline
\end{tabular}

\subsection{The basic medical school of this university calculates education cost by traditional accounting method and activity-based costing method respectively}

If the average student cost is calculated according to a single standard allocation:

The total cost of education in 2018 is 45.35 million yuan $\div$ the total number of students in the school is $16,172=27,800$ yuan

Calculate the average student cost of basic medical school by using activity-based costing:

The distribution cost is 33.71 million yuan $\div 816$ people $=41,300$ yuan

According to the above calculation results, the average student cost of the basic medical school in 2018 was 13,500 yuan higher than the average cost of a single standard in the whole school, exceeding by about 45 percentage points.Taking all factors into consideration, basic medical students with medical background enjoy more professional teachers, laboratory teaching guidance, scientific research and daily management than the average level of the whole school.

According to the empirical calculation, it can be found that the cost information calculated by activity-based costing method is applicable to the cost accounting of a single "product", and through the cost calculation process, the cost drivers are analyzed to find the cost influencing factors.

\section{Feasibility analysis of the application of activity-based costing in college education cost accounting}

From the process of empirical research in this paper, it is not difficult to find that the connotation of ABC theory and education cost accounting requirements is matched. Compared with traditional accounting methods, activitybased costing changes the indirect cost allocation process and makes the cost accounting results more accurate. China's colleges and universities have initially met the relevant conditions of using activity-based costing. 


\section{1 "Flat" administrative organization of colleges and universities}

In the institutional setup of colleges and universities in China, second-level colleges and departments generally undertake direct production tasks such as teaching tasks, student management and discipline construction, firstlevel functional departments are responsible for indirect tasks such as administrative management, teaching assistance and logistics services, and second-level colleges and departments and first-level functional departments are interrelated. Under the $\mathrm{ABC}$ costing method, the allocation path of resources is short, and the "flat" organization makes the process of "operation" not too long, which makes the risk and cost of implementing activity-based costing relatively low.

\subsection{The cost of higher education is characterized by repeatability and more indirect costs}

In fact, college education is a cyclical process of repeated production. Each class of students from freshmen to graduation, teaching activities of each grade are roughly the same. From the perspective of cost accounting, colleges and universities have a repetitive and stable operation process.

\subsection{Colleges and universities have good conditions for software and hardware promotion}

Under the strategic decision and deployment of building a world-class university and a first-class discipline "double first-class", universities are required to carry out scientific quantitative assessment on teaching, scientific research, administration and other aspects of management, and strive to make the operation process more concise and the operation results more clear. At the same time, no matter it is student management, education and teaching, book borrowing, financial reimbursement and so on have carried on information management, which provides a good software and hardware environment for the application of $\mathrm{ABC}$.

In summary, this article uses the activity-based costing method to calculate the education cost of a Chinese medicine university, which is more systematic and accurate than the traditional cost accounting method. At the same time, most colleges and universities have the relevant conditions for the application of activity-based costing, and believe that it is necessary to apply the activity-based costing method to the existing accounting system.Clarify the situation of resource consumption, and then make reasonable resource allocation decisions to improve the comprehensive management capabilities of colleges and universities.

\section{Fund project:}

This paper is the periodical achievement of the key project of Hubei Provincial Education Science Planning
(2019GA029) "Research on Innovation of Undergraduate Talents Training Mode of Economics and Management in Local Universities".

\section{References}

1. Q.G. Tao, X.L. Zhu, S.H. Dai, Friends of Accounting, 18, 94-99(2016)

2. S.H. Shao, Z.W. Hu, Friends of Accounting, 07, 146148(2018)

3. S.P. Gu, F.Y. Gu, Finance and Accounting Bulletin, 26, 86-8(2016)

4. T.M. Yan, Educational Accounting Research, 28 ,1821(2017)

5. L.H. Zhao, Y. Zuo, Higher Education Journal, $04,55-57(2019)$ 